\title{
Burden of acute respiratory disease of epidemic and pandemic potential in the WHO Eastern Mediterranean Region: A literature review
}

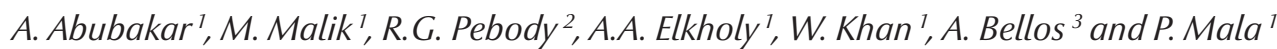

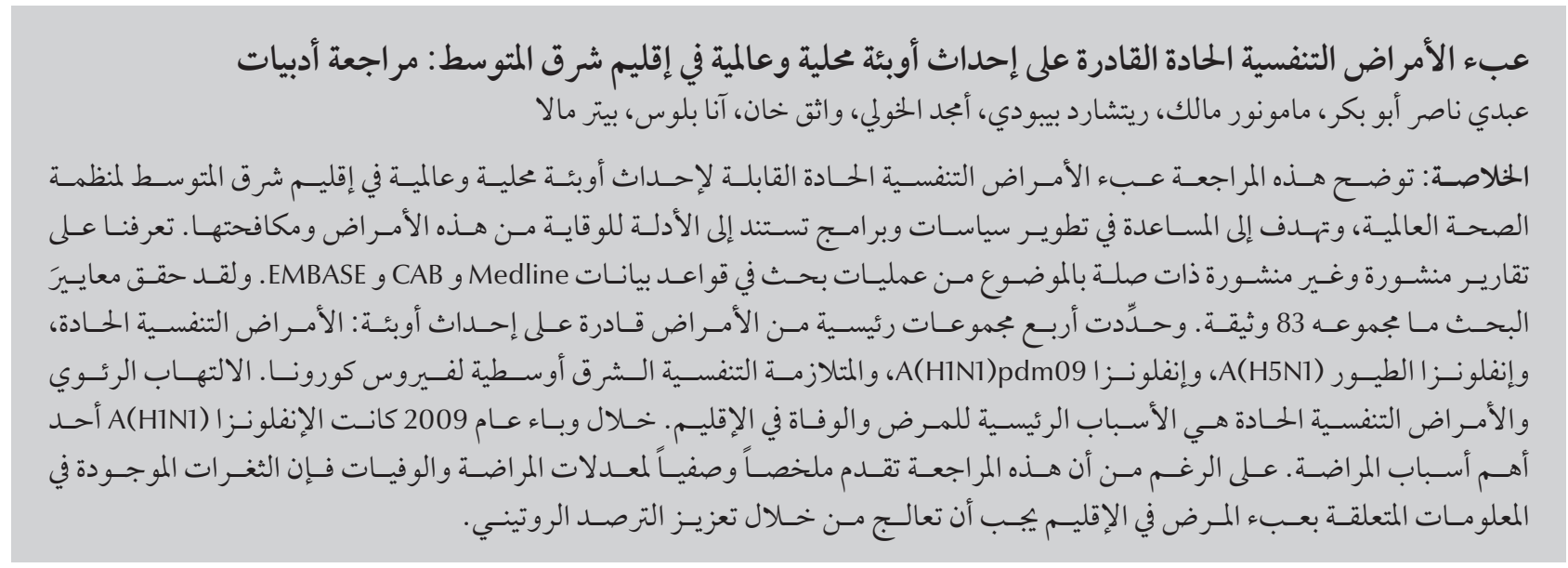

ABSTRACT There are gaps in the knowledge about the burden of severe respiratory disease in the Eastern Mediterranean Region (EMR). This literature review was therefore conducted to describe the burden of epidemicand pandemic-prone acute respiratory infections (ARI) in the Region which may help in the development of evidence-based disease prevention and control policies. Relevant published and unpublished reports were identified from searches of various databases; 83 documents fulfilled the search criteria. The infections identified included: ARI, avian influenza $A(\mathrm{H} 5 \mathrm{~N} 1)$, influenza $\mathrm{A}(\mathrm{H} 1 \mathrm{N1})$ pdm09 and Middle East respiratory syndrome coronavirus (MERS-CoV) infection. Pneumonia and ARIs were leading causes of disease and death in the Region. Influenza $\mathrm{A}(\mathrm{H} 1 \mathrm{N1})$ was an important cause of morbidity during the 2009 pandemic. This review provides a descriptive summary of the burden of acute respiratory diseases in the Region, but there still remains a lack of necessary data.

\section{Charge des infections respiratoires aiguës à potentiel épidémique et pandémique dans la Région OMS de la Méditerranée orientale : analyse documentaire}

RÉSUMÉ On observe des lacunes en matière de connaissances concernant la charge des maladies respiratoires sévères dans la Région de la Méditerranée orientale. La présente analyse documentaire détaille la charge des infections respiratoires aiguës (IRA) à potentiel épidémique et pandémique dans la Région, ce qui peut aider à l'élaboration de politiques et programmes de prévention et de lutte contre les maladies reposant sur des données factuelles. Des articles pertinents publiés et non publiés ont été identifiés grâce à des recherches dans différentes bases de données ; 83 documents satisfaisaient à nos critères de recherche. Les infections identifiées comprenaient les infections respiratoires aiguës (IRA), la grippe aviaire A(H5N1), la grippe A(H1N1)pdm09 et l'infection par le coronavirus du syndrome respiratoire du Moyen-Orient (MERS-CoV). La pneumonie et les IRA constituaient les principales causes de morbidité et de mortalité dans la Région. La grippe A(H1N1) était une cause importante de morbidité durant la pandémie de 2009. Cette analyse fournit un résumé descriptif de la charge des maladies respiratoires aiguës dans la Région mais il existe toujours une lacune concernant les donneés nécessaires à cet égard. 


\section{Introduction}

Acute respiratory infection (ARI) is consistently ranked among the top causes of morbidity and mortality worldwide. It has been referred to as a "forgotten pandemic", which kills more than 4 million people each year globally (1).

Acute respiratory illnesses can range from asymptomatic and mild infections, such as those often caused by rhinoviruses, to high case fatality diseases due to infections such as avian influenza and Middle East respiratory syndrome coronavirus (MERS-CoV). The burden of pneumonia as the primary cause of mortality among children under 5 years of age is well established (2). Worldwide, ARIs are the third most common cause of mortality in all ages, particularly in lower income settings (1).

Common bacterial and viral pathogens causing severe respiratory disease, such as pneumococcal disease and seasonal influenza, for which interventions exist, continue to be a threat. Emerging zoonoses causing respiratory disease, such as avian influenza and more recently MERS-CoV, in an immunologically naïve population are a concern for global health security. There are very real epidemiological and economic consequences in the event of uncontrolled transmission of these novel pathogens (3).

Recognizing gaps in the knowledge regarding the burden of severe respiratory disease in the Middle East, the World Health Organization (WHO) Regional Office for the Eastern Mediterranean Region is taking steps to improve surveillance for respiratory illness (3) in order to support evidence-based decision-making in policy development.

Therefore, to provide a baseline description of the burden of severe respiratory disease with epidemic and pandemic potential in the Eastern Mediterranean Region (EMR), we conducted a literature review of the published and unpublished literature.

\section{Methods}

The Cochrane Library database of systematic reviews was searched from 2000 to June 2015, initially to ensure that a similar literature review of the burden of acute respiratory diseases in the EMR was not already in existence. No such reviews were found.

For this review we included published and unpublished reports of the epidemiological burden of respiratory disease of epidemic and pandemic potential. The search included literature published or produced between 1995 and May 2015; 1995 was chosen as the lower limit based on an initial screening and assessment of the quality of studies prior to this date. In addition, limiting the results to the past 20 years provides a relevant time frame, given the emerging nature of some of the respiratory illnesses of importance.

The literature search was conducted from April to June 2015. We searched Medline, $\mathrm{CAB}$ and Embase databases using the OVID SP interface. The Index Medicus of the Eastern Mediterranean was searched using simple keyword searches. In addition, the websites of ministries of health and related ministries of all countries in the EMR were searched to find all potential reports on the burden of the diseases of interest. Websites of WHO and the Centers for Disease Control (CDC) in the United States of America (USA) were hand searched for relevant documents, and the Google search engine was used to search for unpublished documents for each country in the EMR. A range of search terms were used for severe acute respiratory illness (SARI) caused by common bacterial and viral pathogens, novel pathogens or those with the capacity to cause epidemics or pandemics that threaten international health security, together with EMR geographical terms.

This review concerns all ARIs with the potential to cause an excess burden of disease, whether caused by common pathogens or novel ones, and which may constitute public health emergencies of local and international concern, as defined by the International Health Regulations 2005 (4). These include:

- SARS;

- human influenza caused by a new subtype (i.e. avian influenza viruses including $\mathrm{H} 5 \mathrm{~N} 1, \mathrm{H} 7 \mathrm{~N} 9, \mathrm{H} 7 \mathrm{~N} 2$ and H9N2, swine flu/pandemic influenza $\mathrm{H} 1 \mathrm{~N} 1$ );

- pneumonic plague;

- novel ARIs that can cause large-scale outbreaks or outbreaks with high morbidity and mortality (human cases of influenza A(H7N9) and MERS $\mathrm{CoV})(5)$.

The 22 countries listed on the website of the WHO Region for the Eastern Mediterranean were used in this literature search (6).

The definition of disease burden used for this literature review is limited to the epidemiological indicators of morbidity and mortality attributed to the ARIs of concern. These indicators include: number of cases, incidence, prevalence, proportionate morbidity (i.e. the number of specific ARI cases either as a percentage of the total number of ARI cases or of all disease cases reported), proportionate mortality rates, case fatality rates (CFRs) and rates of hospitalization.

References were reviewed and relevant data were abstracted onto a standard proforma spreadsheet. Data abstracted were used to summarize the reported burden of ARIs in the EMR.

Incidence rates were normalized to 10 000-person years to allow comparisons where possible. Data obtained from weekly epidemiological bulletins, specifically from the Syrian Arab Republic for 2015 (7), were entered into a 
separate data abstraction spreadsheet to obtain cumulative numbers of cases and proportional morbidities.

\section{Results}

Peer reviewed electronic database search resulted in the identification of 1789 articles. A further 2390 were retrieved from websites including $\mathrm{WHO}$, CDC, Google, ministries of health and references of other articles. Of these, 3812 were duplicates or were excluded based on title and abstract screening. Full text was screened in 367 documents. Two-hundred and eighty-four documents were screened out due to lack of applicable data, an inability to obtain full text, or meeting at least one exclusion criteria. Eighty-three articles were retained that contained at least one indicator of burden. Figure 1 shows a flow diagram of the number of papers/ documents identified and excluded at each step.

Overall, there is a general underrepresentation of reporting on the burden of disease in most countries of the EMR, with no specific trend seen related to country income classification (8) (Figure 2).

\section{Human influenza A(H5N1)}

Twenty-one papers were identified. Globally, and among the EMR countries with human influenza $\mathrm{A}(\mathrm{H} 5 \mathrm{~N} 1)$, Egypt has the highest total number of cases (9). As of 30 April 2015 the total number of cases in Egypt was 342, or $41 \%$ of the total number of cases recorded globally (10). The high number of cases is attributed to poultry outbreaks and contact with infected poultry, but there is no evidence so far of a change in human-human transmission (9).

The percentage of confirmed $\mathrm{H} 5 \mathrm{~N} 1$ cases in Egypt was highest in the 30-45 years age group; however, only two papers report this information $(11,12)$. The only other report to cite a median age group was a report of Egypt's first
85 cases, for which the median age was 6 years (13).

Deaths attributed to influenza $\mathrm{A}(\mathrm{H} 5 \mathrm{~N} 1)$ in the EMR are mostly within Egypt (114 of the global 447 deaths to date) (9). Case fatality for influenza $\mathrm{A}(\mathrm{H} 5 \mathrm{N1})$ has remained fairly stable over the last 10 years, with reports from 2006-2009 to 2015 all quoting $29 \%$ to $33 \%$ for country-specific rates $(9,10,11)$. Iraq has the highest reported CFR at $67 \%$ (2 deaths out of 3 confirmed cases) (11).

Data on the age distribution of H5N1 deaths are only available from Egypt, where a median age of 25 years was reported (13), with the age-specific CFR reported to be highest among those aged 45 years and older at $47 \%$ (10). The only confirmed fatality reported in Pakistan was a 27-year-old family contact of the index case (14).

\section{Human influenza A(H1N1)}

Pandemic influenza $\mathrm{A}(\mathrm{H} 1 \mathrm{~N} 1)$, also known as swine flu, is currently in the post-pandemic phase and is behaving like seasonal influenza (15). All 26 articles in the Region reporting some measurement of morbidity and/ or mortality are from the 2009/10 A(H1N1)pdm09 pandemic. Papers were identified from 8 countries and describe the morbidity and mortality in pandemic cases confirmed by real-time reverse-transcriptase polymerase chain reaction (RT-PCR). More studies were from the Islamic Republic of Iran and Saudi Arabia than other countries of the Region.

Most of the papers reviewed were hospital- or health care-based studies documenting the proportion of suspected influenza cases that tested positive for $\mathrm{A}(\mathrm{H} 1 \mathrm{~N} 1) \mathrm{pdm} 09$. One study, a suspected community outbreak of $\mathrm{A}(\mathrm{H} 1 \mathrm{~N} 1)$ pdm09 in a training institute in the Eastern Province in Saudi Arabia, resulted in community case finding and isolation of suspected cases in an attempt to control the epidemic (16). National surveillance data were reported and analysed in other studies (17-22).

A study in Morocco in 2009 used patients presenting with SARI and influenza-like illness (ILI) to hospitals and health centres as the study population. They were able to determine the percentage of cases that were positive for influenza in general (37\%) and for pandemic influenza $A(\mathrm{H} 1 \mathrm{~N} 1)$ pdm09 specifically (96\% of influenza-positive cases), showing that $\mathrm{A}(\mathrm{H} 1 \mathrm{~N} 1) \mathrm{pdm} 09$ was the dominant influenza strain (19).

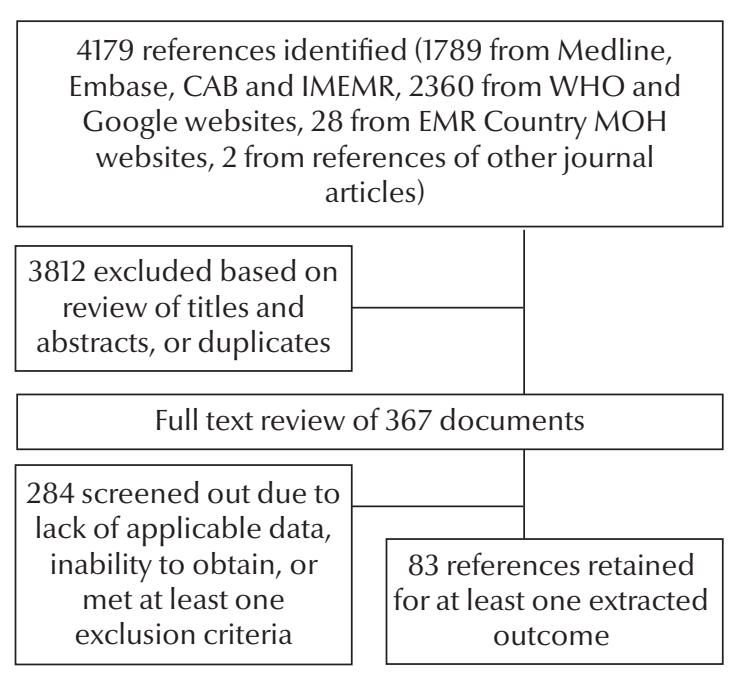

Figure 1 Summary of references identified and studies abstracted 


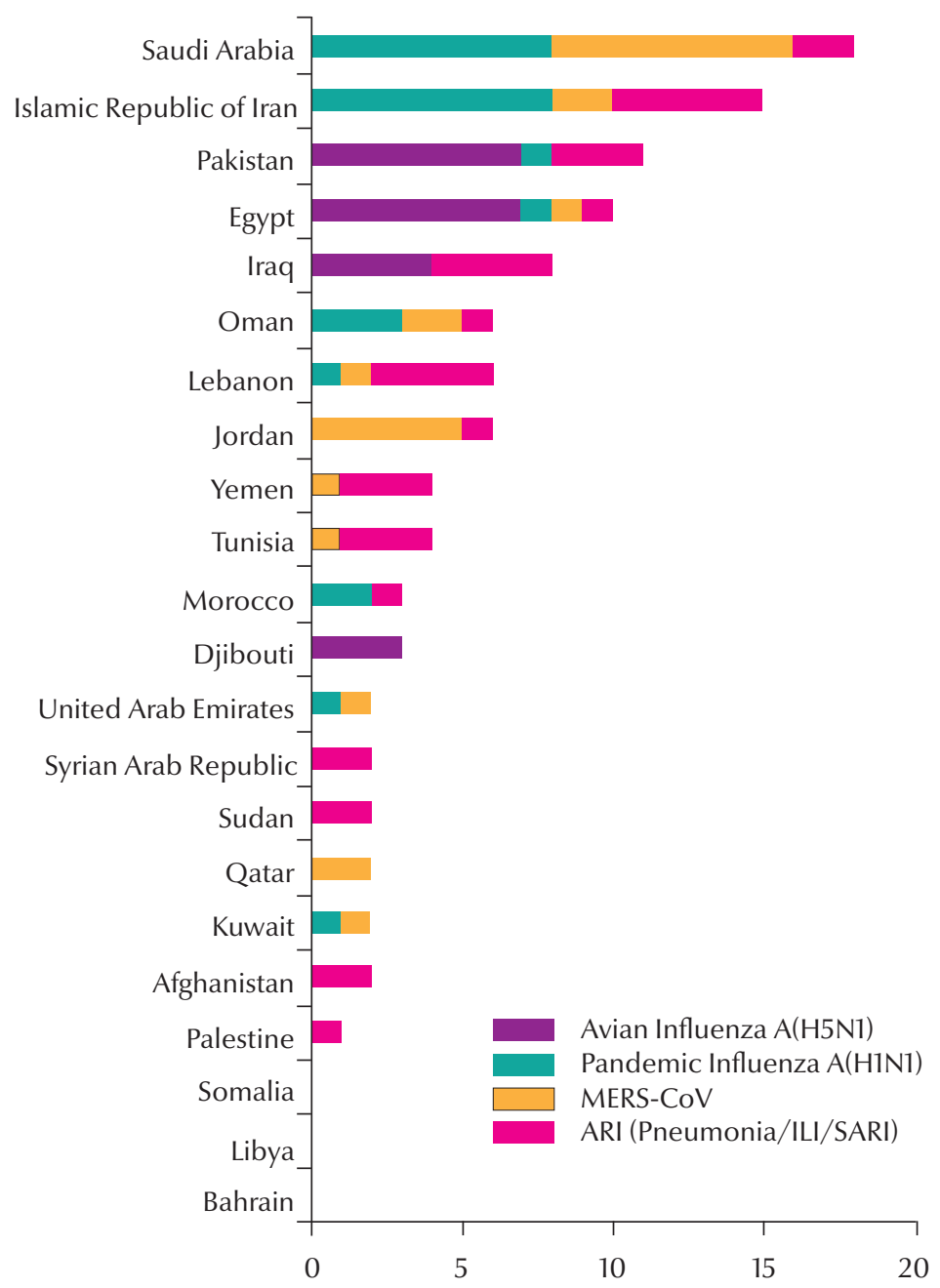

Figure 2 Countries in which burden information was extracted for this review, by disease and country

Disease due to $\mathrm{A}(\mathrm{H} 1 \mathrm{~N} 1) \mathrm{pdm} 09$ appeared to affect mainly adults with mean and median ages in the 20-30year age group; the highest proportionate morbidity was in the age group 20-50 years. A risk factor assessment from Hamedan Province, Islamic Republic of Iran found that pregnant women and those aged 20-39 years were at increased risk of $\mathrm{A}(\mathrm{H} 1 \mathrm{~N} 1)$ pdm09 infection (23). The absence of severe disease in children was likely a result of them being missed by surveillance systems detecting $\mathrm{A}(\mathrm{H} 1 \mathrm{~N} 1)$ pdm09. In papers that reported the sex distribution of confirmed $\mathrm{A}(\mathrm{H} 1 \mathrm{~N} 1)$ pdm09 cases, no significant gender differences were found.
The CFR for $\mathrm{A}(\mathrm{H} 1 \mathrm{~N} 1)$ pdm09 was $0 \%$ in Saudi Arabia in all studies reporting mortality $(16,18,24,25)$. A CFR of $16.7 \%$ was observed in Rawalpindi, Pakistan among patients presenting to the pulmonary and critical care department (26). In Morocco, CFR was 19\% in $\mathrm{A}(\mathrm{H} 1 \mathrm{~N} 1)$ pdm09 cases admitted to hospital with SARI (19).

\section{Middle East respiratory syndrome (MERS-CoV) infection}

Twenty-five papers were identified. Generally, the proportionate morbidity of MERS-CoV decreased in all countries affected from 2012 to 2015, except in Saudi Arabia and the United Arab Emirates where the contribution to the global case load continues to increase. These two countries are ranked 1st and 2 nd respectively in numbers of cases among affected countries (27).

All documents describing the burden of MERS-CoV in countries of the EMR detail experiences in hospital inpatient settings, despite some acquisition in the community. Nosocomial transmission of MERS-CoV was first seen in an outbreak in Zarqa, Jordan in 2012 (28), which affected a high proportion of health care workers $(28,29)$.

During an outbreak in Al-Ahssa, Saudi Arabia, in April and May 2013, $68 \%$ of cases were laboratory confirmed and $94 \%$ of those were acquired in hospitals (30). Another outbreak reported in Saudi Arabia, in Eastern Province in 2013, resulted in $17 \%$ of suspected cases confirmed for MERS-CoV (31). A study of inpatient data from hospitals that did not experience active outbreaks throughout Saudi Arabia found that only $2.1 \%$ of critically ill patients admitted with lower respiratory infection and fever tested positive for MERS-CoV infection (32).

No cases were detected in children under 2 years of age in Jordan (33). In Saudi Arabia, $8 \%$ of critically ill patients admitted for fever and lower respiratory tract infection were children under 17 years of age (32). The age of MERS$\mathrm{CoV}$ patients ranged between a median of 33 years in Zarqa, Jordan (28) and 62 years in Riyadh, Saudi Arabia (34). A retrospective study of all patients diagnosed with laboratory-confirmed MERS-CoV infection in Saudi Arabia, both health-care-associated and community-acquired, reported age-specific morbidity and mortality rates at one centre over 20 months (34). In this study, $47.1 \%$ of lab confirmed MERS$\mathrm{CoV}$ patients were aged $\geq 65$ years. Mortality was high (60\%) and age $\geq 65$ years was the only independent risk factor for mortality (odds ratio 4.39; $95 \%$ confidence interval 2.13-9.05) (34). 
Between 2012 and 2015, a CFR of $38 \%$ for MERS-CoV was reported to WHO from the EMR (27). For MERS$\mathrm{CoV}$ in inpatient settings, the CFR initially reported after the Zarqa Jordan hospital outbreak in 2012 was $100 \%$ because both confirmed cases died; however, this was reduced to $15 \%$ when the total number of confirmed and probable cases was used as the denominator (28). The seroepidemiologically-confirmed CFR for the same outbreak was $22 \%$ for all cases and $16.7 \%$ in health care workers (29). In Saudi Arabia, a CFR of 76\% was reported in cases of MERS-CoV confirmed by nasopharyngeal swabs or tracheal aspirates (31).

\section{Acute respiratory infections}

Respiratory infections caused by common bacterial and viral pathogens are included in the definition of epidemicand pandemic-prone diseases. Thirtyfive papers reporting ARI (including pneumonia, influenza-like illness and severe acute respiratory infection) were eligible for this review (Tables 1-3). While some studies reported sex distribution for ARI cases, no specific pattern or trend was apparent.

\section{Incidence or prevalence of ARI (Table 1)}

Point prevalence of communityacquired pneumonia in inpatients in Saudi Arabia was 30.3\%, with the

\begin{tabular}{|c|c|c|c|c|c|}
\hline Disease & $\begin{array}{l}\text { Population at risk (year) } \\
\text { (reference) }\end{array}$ & Study design & $\begin{array}{l}\text { Case definition } \\
\text { as reported }\end{array}$ & $\begin{array}{c}\text { Prevalence (\%) or incidence per } \\
10000 \text { person-years } \\
\text { (age, if available) }\end{array}$ & $\begin{array}{l}\text { Rank (relative } \\
\text { importance) }\end{array}$ \\
\hline \multicolumn{6}{|l|}{ Inpatient } \\
\hline Pneumonia & $\begin{array}{l}\text { Riyadh, Saudi Arabia } \\
\text { All patients at King Fahad } \\
\text { National Guard Hospital (2013) } \\
\text { (35) }\end{array}$ & $\begin{array}{l}\text { Point } \\
\text { prevalence } \\
\text { survey }\end{array}$ & $\begin{array}{l}\text { Community } \\
\text { acquired } \\
\text { pneumonia }\end{array}$ & $\begin{array}{c}\text { Overall } 30.3 \% \\
(43.4 \% 50+y, 17.1 \% 40-49 \text { y, 3.9\% } \\
30-39 \text { y, } 6.6 \% 20-29 y, 6.6 \% \\
10-19 y, 14.5 \% 1-9 y, 7.9 \%<1 y)\end{array}$ & 2nd of 5 \\
\hline \multicolumn{6}{|c|}{ Inpatient \& Outpatient } \\
\hline RSV infection & $\begin{array}{l}\text { Damanhour, Egypt } \\
\text { Population-based surveillance } \\
\text { of ARI in } 3 \text { hospital and } 3 \\
\text { outpatient settings (2009-2012) } \\
\text { (47) }\end{array}$ & $\begin{array}{l}\text { Descriptive } \\
\text { cross- } \\
\text { sectional }\end{array}$ & $\begin{array}{l}\text { RSV associated } \\
\text { hospitalization } \\
\text { RSV associated } \\
\text { outpatient visits }\end{array}$ & $\begin{array}{c}2.4^{\mathrm{a}}\left(174.5^{\mathrm{a}} \text { in children }<1 \mathrm{y}\right) \\
60.8^{\mathrm{b}}\end{array}$ & \\
\hline \multicolumn{6}{|l|}{ Outpatient } \\
\hline ALRI & $\begin{array}{l}\text { Bam, Islamic Republic of Iran } \\
\text { Post-earthquake assessment of } \\
\text { disease (2004) (36) }\end{array}$ & $\begin{array}{l}\text { Descriptive } \\
\text { cross- } \\
\text { sectional }\end{array}$ & $\begin{array}{l}\text { Lower } \\
\text { respiratory } \\
\text { tract infection }\end{array}$ & $312^{\mathrm{c}}$ & $3 r d$ \\
\hline \multicolumn{6}{|l|}{ Surveillance } \\
\hline ARI & $\begin{array}{l}\text { Karachi, Pakistan } \\
\text { Community surveillance in } 4 \\
\text { peri-urban communities in } \\
\text { Pakistan }(2002 / 03)(37)\end{array}$ & $\begin{array}{l}\text { Cross } \\
\text { sectional } \\
\text { survey }\end{array}$ & $\begin{array}{l}\text { Acute } \\
\text { respiratory } \\
\text { infection }\end{array}$ & $4403^{d}$ & \\
\hline ALRI & & & $\begin{array}{l}\text { Pneumonia } \\
\text { and severe } \\
\text { pneumonia }\end{array}$ & $821^{\mathrm{e}}$ & \\
\hline \multirow[t]{2}{*}{ ARI } & $\begin{array}{l}\text { Sudan EWARS communicable } \\
\text { disease weekly bulletin } \\
(2013 / 14)(38,39)\end{array}$ & & ARI & $\begin{array}{l}\text { Range low to high: } \\
239 \text { to } 848^{f}\end{array}$ & 1 st \\
\hline & $\begin{array}{l}\text { West Darfur }(38,39,69-72) \\
\text { North Darfur }(38,39,69-72) \\
\text { Population of Oman (2013) (40) }\end{array}$ & & $\begin{array}{c}\text { ARI } \\
\text { ARI } \\
\text { ARI in }<5 \text { year } \\
\text { olds }\end{array}$ & $\begin{array}{c}759 \text { to } 1149^{\mathrm{g}} \\
1206 \text { to } 1721^{\mathrm{h}} \\
11200^{\mathrm{i}}\end{array}$ & $\begin{array}{l}\text { 1st } \\
1 \text { st }\end{array}$ \\
\hline Influenza & $\begin{array}{l}\text { Syrian Arab republic } \\
\text { All governates. (2013) (73) }\end{array}$ & & Report & $\begin{array}{l}\text { Cases influenza reported by health } \\
\text { facilities }\end{array}$ & $\begin{array}{c}30482 \\
\text { cases/month }\end{array}$ \\
\hline & Yemen, national data (2013) (74) & & $\begin{array}{c}\text { Annual } \\
\text { statistical } \\
\text { health report }\end{array}$ & Cases of influenza & $\begin{array}{c}40602 \\
\text { cases/year }\end{array}$ \\
\hline
\end{tabular}

$A L R I=$ acute lower respiratory infection; EWARS = early warning and response system; $R S V=$ respiratory syncytial virus; $y=y e a r s$.

${ }^{a}$ Reported as 24 per 100000 person-years and 1745 per 100000 person-years. ${ }^{b}$ Reported as 608 per 100000 person-years. ${ }^{c}$ Reported as 26 per 10000 personmonths. ${ }^{d}$ Reported as 440.3 per 1000 per year. ${ }^{e}$ Reported as 82.1 per 1000 per year. ${ }^{f}$ Reported as 4.6 to 16.3 per 10000 per week. ${ }^{g}$ Reported as 14.6 to 22.1 per 10000

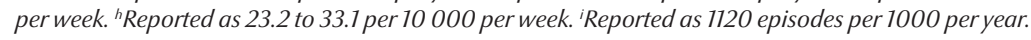




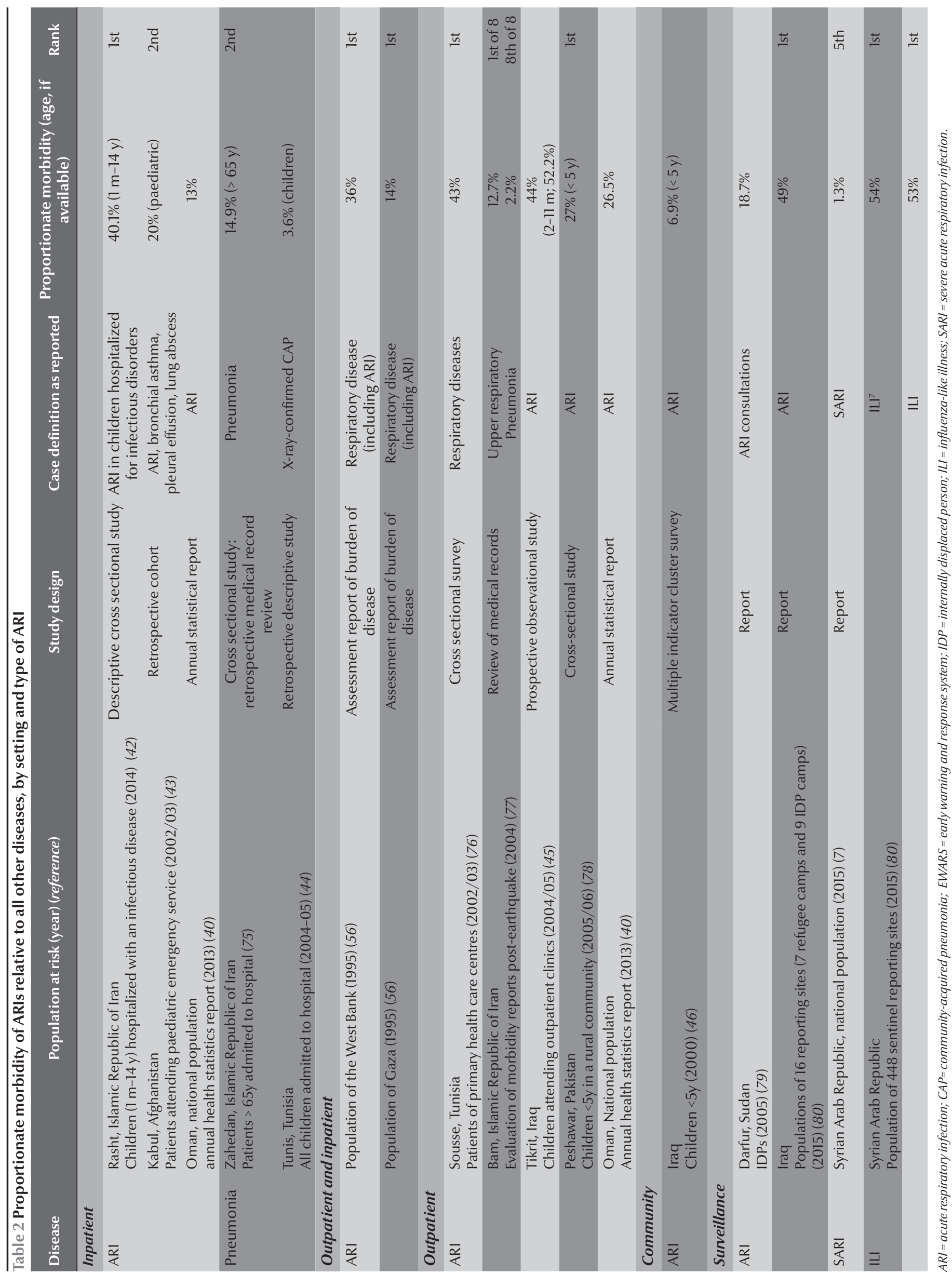




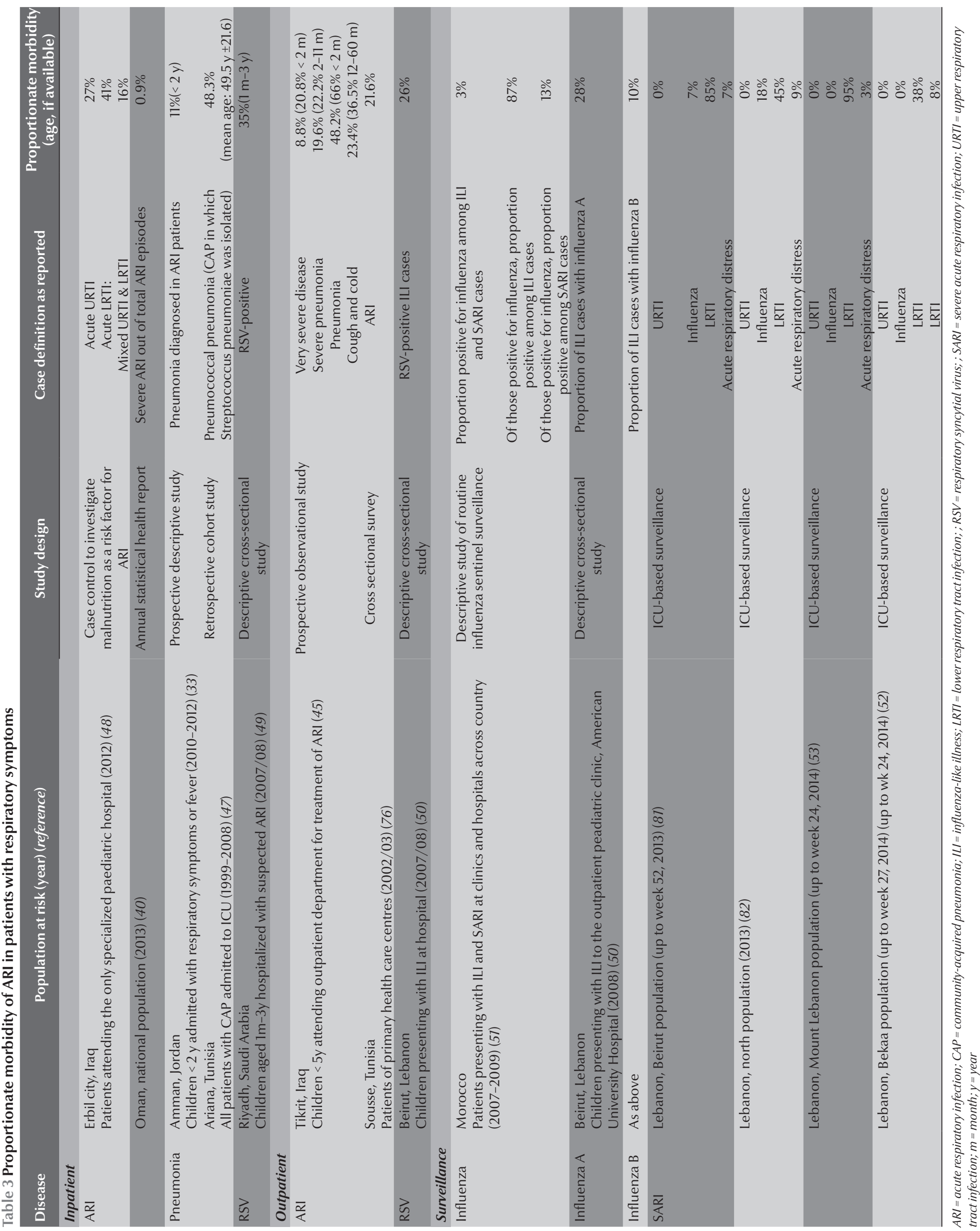




\begin{tabular}{|c|c|c|c|c|}
\hline Disease & Place (year) (reference) & Case definition, as reported & Mortality burden data & Rank \\
\hline \multicolumn{5}{|c|}{$A R I$ - proportionate mortality } \\
\hline & Kabul, Afghanistan (2002/03) (43) & $\begin{array}{l}\text { ARI as cause of child } \\
\text { mortality }\end{array}$ & $22 \%$ & 2nd \\
\hline & Herat province, Afghanistan (2004) (54) & $\begin{array}{c}\text { ARI as cause of child } \\
\text { mortality }\end{array}$ & $30.5 \%$ & $1 s t$ \\
\hline & Karachi, Pakistan (2010) (55) & $\begin{array}{l}\text { "Respiratory tract" as cause of } \\
\text { child mortality }\end{array}$ & $28.7 \%$ & 1 st \\
\hline & Oman, annual health report (2013) (40) & $\begin{array}{l}\text { Primary ARI deaths in } \\
\text { children }<5 y\end{array}$ & $\begin{array}{l}16 \text { deaths out of } 383 \\
272 \text { ARI episodes }\end{array}$ & \\
\hline \multicolumn{5}{|c|}{ Pneumonia - proportionate mortality } \\
\hline \multicolumn{2}{|c|}{ West Bank and Gaza (1997) (56) } & $\begin{array}{l}\text { Pneumonia/respiratory } \\
\text { disease }\end{array}$ & $\begin{array}{c}\text { All ages: } 8.6 \% \\
<1 \text { y: } 22 \% ; \\
\text { 1-<5 y: } 19 \% ; \\
5-19 \text { y: } 12 \% \\
20-39 \text { y: } 4 \% \\
40-59 \text { y: } 3 \% \\
60+\text { y: } 5 \%\end{array}$ & $\begin{array}{l}\text { 4th of } 15 \\
1 \text { st of } 10 \\
1 \text { st of } 10 \\
3 \text { rd of } 10 \\
6 \text { th of } 10 \\
7 \text { th of } 10 \\
6 \text { th of } 10\end{array}$ \\
\hline & $\begin{array}{l}\text { Ariana, Tunisia } \\
(1999-2008)(47)\end{array}$ & $\begin{array}{l}\text { Mortality in Streptococcus } \\
\text { pneumoniae-confirmed } \\
\text { pneumonia cases }\end{array}$ & $25 \%$ & \\
\hline & $\begin{array}{l}\text { Islamic Republic of Iran (Tehran, Karaj, } \\
\text { Savojbaolagh, Robatkarim, Shahriar) } \\
(2005 / 06)(57)\end{array}$ & $\begin{array}{l}\text { Pneumonia as cause of death } \\
\text { in }<5 \text { year-olds }\end{array}$ & $\begin{array}{l}<5 \mathrm{y}: 4.8 \% \\
1-12 \mathrm{~m}: 27 \% \\
1-5 y: 16.6 \%\end{array}$ & $\begin{array}{l}3 r d \\
1 s t \\
1 s t\end{array}$ \\
\hline \multicolumn{5}{|c|}{ ARI - case fatality rate } \\
\hline & Kabul, Afghanistan (2002/03) (43) & $\begin{array}{c}\text { ARI as cause of child } \\
\text { mortality }\end{array}$ & $16 \%$ & 8th of 9 \\
\hline
\end{tabular}

$m=$ month $; y=$ year .

highest prevalence in those aged 50 years and older (35).

Lower respiratory tract infections after an earthquake in Bam, Islamic Republic of Iran had the 3rd highest incidence of all diseases measured after the earthquake, at 312 per 10000 person-years (36).

Community surveillance in Karachi Pakistan showed that incidence of ARI was 4403 per 10000 person-years, and that incidence of pneumonia and severe pneumonia was 821 per 10000 person years (37). Weekly early warning and response system reports (EWARS) in Sudan for 9 weeks at the end of 2014/ beginning of 2015 showed that ARI had the highest incidence for reportable disease in three regions of Darfur. The lowest weekly incidence seen in South Darfur was 239 per 10000 person-years during week 52, 2014 (38), while the highest incidence in North Darfur was 1721 per 10000 person-years during week 2, 2015 (39). National data from Oman in 2013 reported that children under 5 years of age experienced 11200 episodes of ARI per 10000 personyears, meaning each child experienced on average 1.12 episodes of ARI per year (40).

Only one paper reported pathogen-specific incidence of ARI. In Damanhour, Egypt, respiratory syncytial virus-associated hospitalization was 2.4 per 10000 person-years, and the incidence of respiratory syncytial virusassociated outpatient visits was 608 per 10000 person-years (41).

\section{Proportionate morbidity of ARI (Table 2)}

Proportionate morbidity of ARI is reported to determine the importance of ARI compared with other illnesses.
Of the 13 papers in which ARI were ranked, 11 ranked them as having the highest or second highest proportionate morbidity.

In children aged 1 month to 14 years in the Islamic Republic of Iran and of "paediatric" age in Afghanistan, respiratory diseases accounted for $40 \%$ (42) and 20\% (43) of inpatient visits respectively, and in Tunisia $3.6 \%$ of all children admitted to hospital had X-rayconfirmed pneumonia in those admitted to hospital (44). ARI accounted for $44 \%$ of morbidity in children attending outpatient clinicsin Tikrit, Iraq (45). According to data analysed from UNICEF multiple indicator cluster survey in Iraq, $6.9 \%$ of childhood disease could be attributed to ARI (46). Morbidity due to ARI in all age groups ranged from $26.5 \%$ in Oman (40) to 49\% in Syria (7). 


\begin{tabular}{|c|c|c|c|c|c|c|c|}
\hline Country & $\begin{array}{l}\text { Location, year } \\
\text { (reference) }\end{array}$ & $\begin{array}{l}\text { Population } \\
\text { at risk }\end{array}$ & $\begin{array}{l}\text { Time at risk } \\
\text { (length of } \\
\text { study) }\end{array}$ & $\begin{array}{c}\text { Rate of } \\
\text { hospitalization of } \\
\text { confirmed cases }\end{array}$ & $\begin{array}{l}\mathrm{ICU} \\
\text { admission } \\
\text { rate }\end{array}$ & $\begin{array}{l}\text { Mean length } \\
\text { of hospital } \\
\text { stay }\end{array}$ & $\begin{array}{l}\text { Pre-existing } \\
\text { condition }\end{array}$ \\
\hline \multicolumn{8}{|l|}{ H1N1 } \\
\hline \multirow[t]{3}{*}{$\begin{array}{l}\text { Islamic } \\
\text { Republic } \\
\text { of Iran }\end{array}$} & $\begin{array}{l}\text { Kurdistan, 2009/10 } \\
\text { (59) }\end{array}$ & $\begin{array}{l}\text { Suspected } \\
\text { cases } \\
\text { attending } \\
\text { hospitals and } \\
\text { health centres }\end{array}$ & $1 \mathrm{yr}$ & $91.7 \%$ & & & \\
\hline & Yazd, 2009/10 (83) & $\begin{array}{l}\text { Patients } \\
\text { registered at } \\
\text { Yazd health } \\
\text { centre }\end{array}$ & $1 \mathrm{yr}$ & $60 \%$ & $30 \%$ & & \\
\hline & Tabriz, 2009 (61) & $\begin{array}{l}\text { Patients } \\
\text { attending Sina } \\
\text { Hospital }\end{array}$ & $3 \mathrm{~m}$ & & $53 \%$ & & \\
\hline \multirow[t]{3}{*}{$\begin{array}{l}\text { Saudi } \\
\text { Arabia }\end{array}$} & $\begin{array}{l}\text { Jeddah, 2009/10 } \\
\text { (25) }\end{array}$ & $\begin{array}{l}\text { Children } \\
\text { presenting to } \\
\text { hospital with } \\
\text { ILI }\end{array}$ & $4 \mathrm{~m}$ & $73 \%$ & & $3.62 \pm 2.05 d$ & \\
\hline & Riyadh, 2009 (58) & $\begin{array}{l}\text { Children } \\
\text { attending } \\
\text { King Khalid } \\
\text { University } \\
\text { Hospital with } \\
\text { ILI }\end{array}$ & $5 \mathrm{~m}$ & $\begin{array}{l}\text { 13\%: median } 3 \text { y }(1 \\
\mathrm{m}-12 \text { y); } 60 \% \text { male, } \\
40 \% \text { female }\end{array}$ & $10 \%$ & & $\begin{array}{l}70 \% \text { of } \\
\text { hospitalized. } \\
100 \% \text { of } \\
\text { those who } \\
\text { died. }\end{array}$ \\
\hline & $\begin{array}{l}\text { Dhahran, } 2009 \\
\text { (84) }\end{array}$ & $\begin{array}{l}\text { Patients } \\
\text { admitted with } \\
\text { ILI }\end{array}$ & $5 \mathrm{~m}$ & 13.4 per 100000 & & $8.5 \mathrm{~d}$ & \\
\hline \multirow[t]{2}{*}{ Oman } & Salalah, 2009 (85) & $\begin{array}{l}\text { Patients }>12 \text { y } \\
\text { presenting at } \\
\text { hospital with } \\
\text { ILI }\end{array}$ & $2 \mathrm{~m}$ & $\begin{array}{c}24 \% \text { : mean age } 35.2 y, \\
60 \% \text { males, } 40 \% \\
\text { females }\end{array}$ & & & \\
\hline & Muscat, 2009 (62) & $\begin{array}{l}\text { H1N1 cases } \\
\text { admitted to } \\
\text { hospital }\end{array}$ & $4 \mathrm{~m}$ & & & $\begin{array}{l}49.2 \% 1-3 \mathrm{~d} \\
43 \% 4-78 \mathrm{~d} \\
7.7 \% 7 \mathrm{~d}\end{array}$ & $70.8 \%$ \\
\hline Kuwait & $2009 / 10(60)$ & $\begin{array}{l}\text { Children } \\
\text { admitted for } \\
\text { influenza }\end{array}$ & $5 \mathrm{~m}$ & 255 patients & $3 \%$ & $4.5 \pm 3.6 \mathrm{~d}$ & $45 \%$ \\
\hline Pakistan & $\begin{array}{l}\text { Rawalpindi, } \\
\text { 2009/10 (26) }\end{array}$ & $\begin{array}{l}\text { Adult patients } \\
\text { presenting to } \\
\text { department } \\
\text { of pulmonary } \\
\text { and critical } \\
\text { care }\end{array}$ & $6 \mathrm{~m}$ & & 27.8 & $10.4 \pm 7.52 \mathrm{~d}$ & \\
\hline \multicolumn{8}{|c|}{ Pneumonia } \\
\hline Tunisia & $\begin{array}{l}\text { Ariana,1998-2008 } \\
(47)\end{array}$ & $\begin{array}{l}\text { All patients } \\
\text { admitted } \\
\text { to ICU with } \\
\text { pneumococcal } \\
\text { pneumonia }\end{array}$ & $9 \mathrm{~m}$ & & & & $\begin{array}{l}\text { Median } 9.5 \mathrm{~d} \\
\quad \text { (range: } \\
1-68 \mathrm{~d})\end{array}$ \\
\hline \multicolumn{8}{|c|}{ MERS-CoV } \\
\hline $\begin{array}{l}\text { Saudi } \\
\text { Arabia }\end{array}$ & $\begin{array}{l}\text { Al-Ahsa \& Riyadh, } \\
\text { 2012/13 (86) }\end{array}$ & $\begin{array}{l}\text { Outbreak of } \\
12 \text { critically ill } \\
\text { patients in ICU }\end{array}$ & $9 \mathrm{~m}$ & & & & $\begin{array}{c}\text { Median } 41 \mathrm{~d} \\
(8-96 \mathrm{~d}), \mathrm{ICU} \\
\text { stay median } \\
30 \mathrm{~d} \text { (range: } \\
\text { 7-104 d) }\end{array}$ \\
\hline
\end{tabular}

$I C U=$ intensive care unit.

ILI - influenza-like illness.

$d=$ day $; m=$ month $y=$ year . 


\section{Disease- and pathogen-specific mor-} bidity of ARI (Table 3)

Disease-specific ARI morbidity was also measured in an attempt to quantify the extent of severe disease among patients with respiratory illness. Children were the target population for all but one of the studies (47) set in inpatient and outpatient settings. Of children admitted to hospital for ARI, $11 \%$ under 2 years old in Amman, Jordan during 2010-2012 had pneumonia, while 41\% in Erbil city, Iraq in 200-2007 had lower respiratory tract infections $(33,48)$. In Tikrit, Iraq, $48.2 \%$ children $<5$ years attending outpatient departments for ARI in 2004/05 had pneumonia (45).

Three studies report pathogenspecific morbidity. Of children aged between 1 month and 3 years with lower respiratory tract infection, 30\% were confirmed to have respiratory syncytial virus (RSV) infections in a Saudi Arabian study (49). Similarly, 26\% of children presenting with ILI at a hospital in Beirut, Lebanon in 2007/08 tested positive for RSV (50). Pneumococcal pneumonia accounted for $48.3 \%$ of patients admitted to the intensive care unit with community-acquired pneumonia in Ariana, Tunisia (47).

Surveillance of ILI and SARI in Morocco revealed that, of the influenzapositive cases, $87 \%$ had ILI (51). Of children in Lebanon presenting with ILI, influenza A was more common (28\%) than influenza B (10\%) (50). Annual statistical reports describing SARI in different areas within Lebanon in $2013 / 14$ indicate that $38 \%$ of SARI cases in Bekaa (52) and 95\% of SARI cases in Mount Lebanon (53) had lower respiratory tract infections.

\section{ARI mortality (Table 4)}

ARI accounted for $22 \%$ of child mortality in Kabul, Afghanistan in 2002/03 (43) and up to $30.5 \%$ of child mortality in Herat province, Afghanistan in 2004 (54). ARI was the primary cause of death among children in Herat and Pakistan, $(54,55)$, and the second most common cause of mortality in Kabul (43).

Pneumonia accounted for $8.6 \%$ of deaths in all ages in the West Bank and Gaza in 1997 (56) and 4.8\% of deaths in children aged under 5 years in the Islamic Republic of Iran in 2005/06 (57). Among laboratory-confirmed Streptococcus pneumoniae pneumonia cases in Ariana, Tunisia between 1999 and 2008 (all over 15 years), 25\% died (47).

The age distribution of deaths due to ARI was described in the West Bank and Gaza and in several cities in the Islamic Republic of Iran (56,57). In both locations, ARI mortality was highest in the under 1-year-old age group, where it was the primary cause of death.

\section{Hospitalization}

The majority of papers reviewed describe morbidity and mortality in hospitalized patients, and specific rates of hospitalizations and lengths of stay were reported in some studies and are shown in Table 5.

By far the greatest amount of information available is for influenza A(H1N1)pdm09. Rates of hospitalization for confirmed cases ranged from $13 \%$ in a paediatric population in Saudi Arabia (58) to $91.7 \%$ in the Kurdistan province of the Islamic Republic of Iran (59). Admission to the intensive care unit for influenza $\mathrm{A}(\mathrm{H} 1 \mathrm{~N} 1)$ pdm09 ranged from $3 \%$ of 255 patients admitted for influenza in Kuwait (60) to 53\% in Tabriz, Islamic Republic of Iran (61). The average length of hospital stay for influenza A(H1N1)pdm09 was lowest in Saudi Arabia (25), Kuwait (60) and Oman (62) and highest in Pakistan (26).

Only one paper each reported duration of hospitalization for pneumonia and MERS-CoV and there were none on duration of hospitalization for influenza $\mathrm{A}(\mathrm{H} 5 \mathrm{~N} 1)$.

\section{Discussion}

After searching the literature, a total of 83 studies were retained. The burden of severe respiratory disease in the EMR was summarized, including burden attributable to specific pathogens, where possible. ARIs of common bacterial and viral origin are important in children and also in the elderly. Global mortality due to pneumonia was estimated at $19 \%$ among < 5-year-olds and $14 \%$ of in children aged 1-59 months in 2008 (63). Data for the EMR extracted in this review suggest that pneumonia and acute respiratory disease are important contributors to child mortality in the Region, ranging between $22 \%$ and $30.5 \%(54,55,56,57,58)$. Novel pathogens and those capable of causing severe excess morbidity and mortality, namely influenza $\mathrm{A}(\mathrm{H} 1 \mathrm{N1}$ )pdm09, $\mathrm{A}(\mathrm{H} 5 \mathrm{N1})$ and MERS-CoV, were found to mainly affect adults.

Influenza $\mathrm{A}(\mathrm{H} 5 \mathrm{~N} 1)$ was reported in four countries in the Middle East. Three of these, Djibouti, Iraq and Pakistan, have had a small number of cases and appear to have controlled the epidemic effectively with no new human cases reported in the last 5 years, according to WHO data (11). Nonetheless, multiple outbreaks of influenza $\mathrm{A}(\mathrm{H} 5 \mathrm{~N} 1)$ in poultry and wild birds have occurred in Pakistan and Iraq since 2006. Egypt continues to report human cases and has the highest number compared to the rest of the world, with the second highest number of fatalities (case fatality $33 \%$ overall and $47 \%$ in the $45+$ years age group). Upsurges have largely been related to uncontrolled poultry farming practices (9), and while we remain in a pre-pandemic alert phase (64), with no change in transmission dynamics between humans at the present time, these findings are a concern. The EMR's contribution to the total global cases and deaths attributable to influenza $\mathrm{A}(\mathrm{H} 5 \mathrm{~N} 1)$ to date is $41.5 \%$ and $24.7 \%$ respectively (11). Further work is needed to understand the risk factors 
for bird-to-human transmission in the EMR, and better prevention and control measures need to be implemented.

The $2009 \mathrm{~A}(\mathrm{H} 1 \mathrm{Nl})$ influenza pandemic was a good example of how a novel strain of transmissible influenza virus can affect an essentially susceptible population. This pandemic is estimated to have caused 201200 deaths worldwide (65). Of the respiratory deaths attributed to $\mathrm{A}(\mathrm{H} 1 \mathrm{~N} 1)$ pdm09, 17900 are estimated to be from the EMR, with a rate of 3.0 per 100000 (66). Mortality rates per 100000 were not cited in any of the papers included in this review. CFRs were reported, however, the highest being 19\% from SARI cases confirmed to have influenza A(H1N1) pdm09 in Morocco (19).

Global data on MERS-CoV infection show that since its initial detection in 2012, Saudi Arabia and the United Arab Emirates continue to be the main contributors to incident cases, reflecting the distribution of the ostensible animal reservoir, the dromedary camel. CFRs were highest for MERS-CoV of all the ARIs discussed in this literature review. MERS - CoV infections in Saudi Arabia account for over $85 \%$ of the global cases (67). Cases continue to appear from either zoonotic exposure (primary cases) or exposure within health care settings (secondary cases) (66). Export of cases to other countries has not resulted in sustained community transmission, with the exception of the Republic of Korea, where extended onward transmission occurred in the health care sector $(66,67)$.

Hospitalization rates and lengths of stay provide some insight into the clinical severity and economic burden of the disease. While this type of information was not plentiful, it is apparent that MERS-CoV infection resulted in severe disease with a median hospital stay of 41 days compared with 10 for pneumonia and pandemic $\mathrm{A}(\mathrm{H} 1 \mathrm{~N} 1)$ pdm09.

This review revealed a number of specific gaps in the available literature. Notably, there is a paucity of disease burden data that are statistically comparable between countries in the EMR. A number of countries had either no or very few reportable data. The target populations were mostly patients attending hospitals or health centres.

Thus, while every effort was made to find all publically available information fulfilling the inclusion criteria for this review, we were unable to perform statistical analysis and pooling of surveillance data to determine the incidence and prevalence of diseases. Such analysis would help improve baseline estimates of disease epidemiology but requires strengthened routine surveillance. Inclusion of burden indicators such as rates and duration of hospitalization will help assess burden in health economic terms as well.

The websites of ministries of health were searched for statistical health reports. Only Egypt, Lebanon, Oman, Syrian Arab Republic and Yemen provided this information publically. Efforts to liaise with ministries of health across the Region to gain access to annual statistical reports and other relevant data would be invaluable. Standardization of methods with respect to annual health reporting would also be beneficial to being able to compare data across countries. Standardization of laboratory methods and more rigorous epidemiological investigation and analysis are also needed.

There are several limitations to this review. Some are a result of the descriptive nature of the papers and the overall quality of the information available for review. Studies were not formally evaluated for their quality or representativeness, and the inconsistencies in research methodologies, case definitions and population denominators made data comparison across studies difficult. In an effort to obtain as much information as possible, wherever morbidity or mortality were reported, the data were summarized in descriptive tables.

This review was Internet-based, which may introduce bias related to the availability of electronic references for review. We believe, however, that all published/peer reviewed articles fitting the selection criteria were found but it is likely that some grey literature and material not openly accessible was missed.

We did not analyse information based on country characteristics. There is a wide disparity in terms of resources, health expenditures, states of crises and displaced populations across the Region and it would be useful to group similar countries with respect to national income, health care access and other pertinent characteristics allowing appropriate comparisons. It has been shown that ARIs are among the top causes of morbidity and mortality in conflict-affected populations (68) and taking this into account when comparing data might have provided another layer of analysis; however, more specific literature search terms and additional sources would have had to have been accessed.

This review looked at pathogen-specific illness and infection $[\mathrm{A}(\mathrm{H} 5 \mathrm{~N} 1)$, $\mathrm{A}(\mathrm{H} 1 \mathrm{N1}$ )pdm09, MERs-CoV, respiratory syncytial virus and S. pneumoniae] as well at diseases diagnosed such as pneumonia or upper respiratory tract infection. In an effort to describe as much respiratory-disease related burden as possible, no strict differentiation between disease and infection was made in this review.

\section{Conclusion}

There is a paucity of statistically comparable information regarding the burden of epidemic and pandemic respiratory diseases in the Region. The papers included in this review allow a descriptive picture of the situation. While it is suspected that the data abstracted for this review are not entirely representative of the whole Region, this summary provides an initial evidence base to support improved surveillance and reporting in the countries of the EMR.

Funding: None.

Competing interests: None declared. 
1. Schluger N. Acute respiratory infections: Making inroads on a forgotten pandemic: The World Lung Foundation; 2010.

2. Pneumonia: Fact Sheet No. 331. Geneva: World Health Organization; 2014

3. Summary report on the Second intercountry meeting on the Eastern Mediterranean Acute Respiratory Infection Surveillance (EMARIS) Network, Sharm el Sheikh, Egypt, 24-27 November 2013 2013. Cairo: World Health Organization; 2013 (WHO-EM/CSR/070/E)

4. International Health Regulations (2005). 2nd ed. Geneva: World Health Organization; 2008.

5. Infection prevention and control of epidemic- and pandemicprone acute respiratory infections in health care. Geneva: World Health Organization; 2014.

6. Countries. Cairo: World Health Organization; 2015 (http:// www.emro.who.int/countries.html, accessed 1 April, 2015).

7. Weekly Bulletin EWARS. Week No.2-18, January-May 2015. Damascus, Syria: PH\&CCD Directorates, Ministry of Health Syria, World Health Organization; 2015.

8. Country and lending groups. Washington DC:The World Bank; 2016 (http://data.worldbank.org/about/country-andlending-groups\#Low_income, accessed March 29, 2016).

9. Egypt: upsurge in H5N1 human and poultry cases but no change in transmission pattern of infection. Cairo: World Health Organization; 2015.

10. WHO. Avian influenza A(H5N1) situation update: 30 April 2015 Egypt. Cairo: World Health Organization; 2015.

11. Cumulative number of confirmed human cases for avian influenza $\mathrm{A}(\mathrm{H} 5 \mathrm{~N} 1)$ reported to $\mathrm{WHO}, 2003-2015$. Cairo: World Health Organization; 2015. (http://www.who.int/influenza/ human_animal_interface/EN_GIP_20150501CumulativeNum berH5N1cases.pdf. Accessed 18 May, 2015).

12. Zaman M, Ashraf S, Dreyer NA, Toovey S. Human infection with avian influenza virus, Pakistan, 2007. Emerg Infect Dis. 2011 Jun;17(6):1056-9. PMID:21749769

13. Fasina FO, Ifende VI, Ajibade AA. Avian influenza $\mathrm{A}(\mathrm{H} 5 \mathrm{~N} 1)$ in humans: lessons from Egypt. Euro Surveill. 201001 28;15(4):19473. PMID:20122384

14. WHO. Human cases of avian influenza $A(\mathrm{H} 5 \mathrm{~N} 1)$ in North-West Frontier Province, Pakistan, October-November 2007. Wkly Epidemiol Rec. 2008 Oct 3;83(40):359-64. PMID:18833663

15. H1N1 in post-pandemic period. Geneva: World Health Organization; 2010; (http://www.who.int/mediacentre/news/ statements/2010/h1n1_vpc_20100810/en/, accessed 1 June 2015).

16. Latif S, Al Fraihi KJ. Novel influenza A (H1N1) outbreak at a training institute in the Eastern Province of Saudi Arabia. Saudi Med J. 2012 Sep;33(9):1021-4. PMID:22964817

17. Ahmed F, Al Hosani F, Al Mannaie A, Harrison O. Early outcomes of pandemic influenza (H1N1) 2009 surveillance in Abu Dhabi Emirate, May-August 2009. East Mediterr Health J. 2012 Jan;18(1):31-6. PMID:22360008

18. AIMazroa MA, Memish ZA, AlWadey AM. Pandemic influenza A (H1N1) in Saudi Arabia: description of the first one hundred cases. Ann Saudi Med. 2010 Jan-Feb;30(1):11-4. PMID:20103952

19. Barakat A, Ihazmad H, El Falaki F, Tempia S, Cherkaoui I, El Aouad R. 2009 Pandemic influenza A virus subtype H1N1 in Morocco, 2009-2010: epidemiology, transmissibility, and factors associated with fatal cases. J Infect Dis. 2012 Dec 15;206 Suppl 1:S94-100. PMID:23169979
20. Annual bulletin of infectious diseases. Cairo: Ministry of Health and Population; 2009.

21. Gouya MM, Nabavi M, Soroush M, Haghdoust AA, Ghalehee $S$, Hemmati $P$, et al. Mortality from pandemic influenza A (H1N1) in Iran. Iran Red Crescent Med J. 2011 Oct;13(10):698701. PMID:22737407

22. Yavarian J, Naseri M, Shadab A, Shafiei Jandaghi NZ, Mokhtari Azad T. Epidemiological aspects of pandemic influenza $\mathrm{A}(\mathrm{H} 1 \mathrm{~N} 1)$ virus from 2009 to 2011 in Iran. Influenza Other Respir Viruses. 2012 Nov;6(6):e74-6. PMID:22487173

23. Cheraghi Z, Doosti Irani A, Rezaiean S, Ahmadzadeh J, Poorolajal J, Erfani H, et al. Influenza A (H1N1) in Hamedan Province, Western Iran in 2009: A Case-Control Study. J Res Health Sci. 201006 24;10(1):15-21. PMID:22911912

24. Mansour MM, Al Hadidib KM. 2009 H1N1 influenza A in children: a descriptive clinical study. Ann Saudi Med. 2012 JanFeb;32(1):59-63. PMID:22156647

25. Herzallah HK, Bubshait SA, Antony AK, Al-Otaibi ST. Incidence of influenza A H1N1 2009 infection in Eastern Saudi Arabian hospitals. Saudi Med J. 2011 Jun;32(6):598-602. PMID:21666942

26. Naseem A, Satti S, Khan MA, Saeed W. A clinical account of hospitalized 2009 pandemic influenza A (H1N1) cases. J Coll Physicians Surg Pak. 2011 Feb;21(2):97-102. PMID:21333241

27. MERS-CoV in 2015: No major spike. Weekly Epidemiological Monitor. 2015;8(18 \& 19).

28. Hijawi B, Abdallat M, Sayaydeh A, Alqasrawi S, Haddadin A, Jaarour $\mathrm{N}$, et al. Novel coronavirus infections in Jordan, April 2012: epidemiological findings from a retrospective investigation/Infections. East Mediterr Health J. 2013;19 Suppl 1:S12-8. PMID:23888790

29. Al-Abdallat MM, Payne DC, Alqasrawi S, Rha B, Tohme RA Abedi GR, et al.; Jordan MERS-CoV Investigation Team. Hospital-associated outbreak of Middle East respiratory syndrome coronavirus: a serologic, epidemiologic, and clinical description. Clin Infect Dis. 2014 Nov 1;59(9):1225-33. PMID:24829216

30. Assiri A, McGeer A, Perl TM, Price CS, Al Rabeeah AA, Cummings DA, et al.; KSA MERS-CoV Investigation Team. Hospital outbreak of Middle East respiratory syndrome coronavirus. $\mathrm{N}$ Engl J Med. 2013 Aug 1;369(5):407-16. PMID:23782161

31. Al-Tawfiq JA, Hinedi K, Ghandour J, Khairalla H, Musleh S, Ujayli A, et al. Middle East respiratory syndrome coronavirus: a case-control study of hospitalized patients. Clin Infect Dis. 2014 Jul 15;59(2):160-5. PMID:24723278

32. Memish ZA, Al-Tawfiq JA, Makhdoom HQ, Al-Rabeeah AA, Assiri A, Alhakeem RF, et al. Screening for Middle East respiratory syndrome coronavirus infection in hospital patients and their healthcare worker and family contacts: a prospective descriptive study. Clin Microbiol Infect. 2014 May;20(5):469-74. PMID:24460984

33. Khuri-Bulos N, Payne DC, Lu X, Erdman D, Wang L, Faouri S, et al. Middle East respiratory syndrome coronavirus not detected in children hospitalized with acute respiratory illness in Amman, Jordan, March 2010 to September 2012. Clin Microbiol Infect. 2014 Jul;20(7):678-82. PMID:24313317

34. Saad M, Omrani AS, Baig K, Bahloul A, Elzein F, Matin MA, et al. Clinical aspects and outcomes of 70 patients with Middle East respiratory syndrome coronavirus infection: a single-center experience in Saudi Arabia. Int J Infect Dis. 2014 Dec;29:301-6. PMID:25303830

35. Balkhy HH, Cunningham G, Chew FK, Francis C, Al Nakhli DJ, Almuneef MA, et al. Hospital- and community-acquired infec- 
tions: a point prevalence and risk factors survey in a tertiary care center in Saudi Arabia. Int J Infect Dis. 2006 Jul;10(4):32633. PMID:16678467

36. Jonaidi Jafari $\mathrm{N}$, Radfar $\mathrm{MH}$, Ghofrani $\mathrm{H}$. Incidence of infectious diseases one month after the bam eartquake (2004). J Med Sci. 2007;7(4):597-602.

37. Nizami SQ, Bhutta ZA, Hasan R. Incidence of acute respiratory infections in children 2 months to 5 years of age in periurban communities in Karachi, Pakistan. J Pak Med Assoc. 2006 Apr;56(4):163-7. PMID:16711336

38. Communicable Diseases Weekly Morbidity and Mortality Bulletin (CDWMMB): Week No. 01: 4-10 Jan 2014. Federal Ministry of Health of Sudan, World Health Organization. Communicable Diseases Weekly Morbidity and Mortality Bulletin; 2014

39. Communicable Diseases Weekly Morbidity and Mortality Bulletin (CDWMMB): Week No. 02: 11-17 Jan 2014. Federal Ministry of Health of Sudan, World Health Organization. Communicable Diseases Weekly Morbidity and Mortality Bulletin; 2014

40. Annual Health Report 2013: Chapter Eight Health Domains. Muscat: Ministry of Health Sultanate of Oman; 2013.

41. Rowlinson E, Dueger E, Taylor T, Mansour A, Van Beneden C, Abukela M, et al. Incidence and clinical features of respiratory syncytial virus infections in a population-based surveillance site in the Nile Delta Region. J Infect Dis. 2013 Dec 15;208 Suppl 3:S189-96. PMID:24265478

42. Moghaddam KB, Dalili S, Asgharzadeh M, Rad AH. Infectious diseases in hospitalised children in Iran. Arch Dis Child. 2014;99 Suppl. 2:A1-620.

43. Prasad AN. Disease profile of children in Kabul: the unmet need for health care. J Epidemiol Community Health. 2006 Jan;60(1):20-3. PMID:16361450

44. Tinsa F, Boussetta K, Gharbi A, Bousnina D, Abdelaziz R, Brini I, et al. [Community acquired pneumonia in children]. Tunis Med. 2009 Dec;87(12):851-6. PMID:20209853

45. Yousif T, Khaleq B. Epidemiology of acute respiratory tract infections (ARI) among children under five years old attending Tikrit general teaching hospital The Middle East Journal of Family Medicine 2006;4(3):4-23.

46. Siziya S, Muula AS, Rudatsikira E. Diarrhoea and acute respiratory infections prevalence and risk factors among under-five children in Iraq in 2000. Ital J Pediatr. 200904 25;35(1):8. PMID:19490665

47. Belkhouja K, Ben Romdhane K, Ghariani A, Hammami A, M'hiri E, Slim-Saidi L, et al. Severe pneumococcal communityacquired pneumonia admitted to medical Tunisian ICU. J Infect Chemother. 2012 Jun;18(3):324-31. PMID:22045164

48. Chalabi DA. Acute respiratory infection and malnutrition among children below 5 years of age in Erbil governorate, Iraq. East Mediterr Health J. 2013 Jan;19(1):66-70. PMID:23520908

49. Al-Majhdi F, Al-Jarallah A, Elaeed M, Latif A, Gissmann L, Amer HM. Prevalence of respiratory syncytial virus infection in Riyadh during the winter season 2007-2008 and different risk factors impact. Int J Virol. 2009;5(4):154-63.

50. Zaraket H, Dbaibo G, Salam O, Saito R, Suzuki H. Influenza virus infections in Lebanese children in the 2007-2008 season. Jpn J Infect Dis. 2009 Mar;62(2):137-8. PMID:19305054

51. Barakat A, Ihazmad H, Benkaroum S, Cherkaoui I, Benmamoun A, Youbi $M$, et al. Influenza surveillance among outpatients and inpatients in Morocco, 1996-2009. PLoS One. 2011;6(9):e24579. PMID:21931764

52. Distribution of verified SARI cases by group and week in Bekaa (Last update: 2014 up to Week27). Beirut: Ministry of Public Health; 2014
53. Distribution of verified SARI cases by group and week in Mount-Lebanon (Last update: 2014 up to Week 25). Beirut: Ministry of Public Health; 2014.

54. Stevens JC, Reilley B, Hargreaves S, Sattar A. A year in Afghanistan-Herat hospital paediatric ward. BrJ Gen Pract. 2004 Oct;54(507):794-5. PMID:15469686

55. Shakoor I, Ghazal R, Fareeduddin M, Noor M. Mortality pattern in children in general pediatric ward of Abbasi Shaheed Hospital Karachi. Medical Forum Monthly. 2014;25(5):55-8.

56. Rionda ZL, Clements A. The burden of disease in the West Bank and Gaza - An assessment report. MEDS. Monitoring, Evaluation and Design Support; 2000.

57. Nojomi M, Naserbakhat M, Ramezany M, Anbary K. Under-5 year mortality: result of an in-hospital study, Tehran, Iran. Acta Med Iran. 2009;47(4):319-24.

58. Al Subaie SS, Al Saadi MA. Features associated with severe disease in hospitalized children with 2009 influenza A (H1N1) infection at a university hospital in Riyadh, Saudi Arabia. Ann Saudi Med. 2012 Jan-Feb;32(1):53-8. PMID:22156640

59. Afrasiabian S, Mohsenpour B, Bagheri KH, Barari M, Ghaderi E, Hashemi R, et al. Epidemiological survey on pandemic influenza A (H1N1) virus infection in Kurdistan province, Islamic Republic of Iran, 2009. East Mediterr Health J. 201404 03;20(3):169-74. PMID:24950074

60. Owayed AF, Husain EH, Al-Khabaz A, Al-Qattan HY, Al-Shammari N. Epidemiology and clinical presentation of pandemic influenza A (H1N1) among hospitalized children in Kuwait. Med Princ Pract. 2012;21(3):254-8. PMID:22133799

61. 61. Saleh P, Noshad H, Naghili B. Demographic and paraclinical findings of patients with novel H1N1infection hospitalized in infectious disease ward, Sina Hospital, Tabriz, Iran. Journal of Zanjan Univeristy of Medical Sciences and Health Services. 2011;19(75):84-93.

62. Pajankar S, Al Qassabi SS, AI Harthi SM. Clinical Features and Outcome of 65 Laboratory Confirmed Cases of H1N1 in Muscat, Sultanate of Oman. Oman Med J. 2012 May;27(3):201-6. PMID:22811768

63. Black RE, Cousens S, Johnson HL, Lawn JE, Rudan I, Bassani DG, et al.; Child Health Epidemiology Reference Group of WHO and UNICEF. Global, regional, and national causes of child mortality in 2008: a systematic analysis. Lancet. 2010 Jun 5;375(9730):1969-87. PMID:20466419

64. Current WHO global phase of pandemic alert: Avian Influenza A(H5N1). Geneva: World Health Organization; 2015 (http://www.who.int/influenza/preparedness/pandemic/ h5n1phase/en/, accessed 19 June, 2015).

65. Dawood FS, Iuliano AD, Reed C, Meltzer MI, Shay DK, Cheng PY, et al. Estimated global mortality associated with the first 12 months of 2009 pandemic influenza A H1N1 virus circulation: a modelling study. Lancet Infect Dis. 2012 Sep;12(9):687-95. PMID:22738893

66. Middle East respiratory syndrome coronavirus (MERS-CoV): summary of current situation, literature update and risk assessment-as of 5 February 2015. Geneva: World Health Organization; 2015.

67. WHO statement on the ninth meeting of the IHR Emergency Committee regarding MERS-CoV. Geneva: World Health Organization; 2015 (http://www.who.int/mediacentre/news/ statements/2015/ihr-ec-mers/en/. Accessed 19 June, 2015).

68. Bellos A, Mulholland K, O'Brien KL, Qazi SA, Gayer M, Checchi F. The burden of acute respiratory infections in crisis-affected populations: a systematic review. Confl Health; 2010. PMID: 20181220 
69. Communicable Diseases Weekly Morbidity and Mortality Bulletin (CDWMMB). Week No. 03: 18-24 Jan 2014. Federal Ministry of Health of Sudan, World Health Organization; 2014.

70. Communicable Diseases Weekly Morbidity and Mortality Bulletin (CDWMMB). Week No. 04: 25-31 Jan 2014. Federal Ministry of Health of Sudan, World Health Organization; 2014.

71. Communicable Diseases Weekly Morbidity and Mortality Bulletin (CDWMMB). Week No. 05: 1-7 Feb 2014. Federal Ministry of Health of Sudan, World Health Organization; 2014.

72. Communicable Diseases Weekly Morbidity and Mortality Bulletin (CDWMMB). Week No. 06: 8-10 Feb 2014. Federal Ministry of Health of Sudan, World Health Organization; 2014.

73. Reported communicable diseases in Syria - October to December 2013. Damascus: Ministry of Health; 2013.

74. Annual statistical health report 2013. Sana'a: Ministry of Health; 2013.

75. Sharifi-Mood B, Metanat M. Spectrum of Clinical Infectious Diseases in Hospitalized Elderly Patients in the Southeast of Iran. Turk J Med Sci. 2007;37(4):213-7

76. Ajmi TN, Amor H, Bougmiza I, Gataa R, Mtiraoui A. [Diagnoses in children seen in general practice in the region of Sousse (Tunisie)]. Sante Publique. 2010 Mar-Apr;22(2):201-11. PMID:20598186

77. Krieg CM, Gardemann J. A record of morbidity and medical request profiles in international humanitarian aid, taking the earthquake in Bam in Iran in 2003 as an example. J Public Health (Bangkok). 2009;17(2):97-106.

78. Khan M, Hussain I, Kazmi N, Majid A, Javaid A. Morbidity and mortality in children in rural community of district Peshawar. Gomal Journal of Medical Sciences. 2009;7(1):31-4.
79. Pinto A, Saeed M, El Sakka H, Rashford A, Colombo A, Valenciano $M$, et al. Setting up an early warning system for epidemic-prone diseases in Darfur: a participative approach. Disasters. 2005 Dec;29(4):310-22. PMID:16277642.

80. P Regional Early Warning and Response Bulletin EmST Amman. Jordan. January 2015. Geneva: World Health Organization; 2015.

81. Distribution of Verified SARI cases by group and week in Beirut (2013 up to week 52). Beirut: Ministry of Public Health; 2013.

82. Distribution of verified SARI cases by group and week in North (Last update: 2013 up to week 52). Beirut: Ministry of Public Health; 2013.

83. Behnaz F, Mohammadzadeh M, Sadeghian M. Household transmission of 2009 H1N1 influenza virus in Yazd, Iran. J Infect Public Health. 2012 Aug;5(4):275-80. PMID:23021649

84. Al-Tawfiq JA, Abed M, Saadeh BM, Ghandour J, Shaltaf M, Babiker MM. Pandemic influenza A (2009 H1N1) in hospitalized patients in a Saudi Arabian hospital: epidemiology and clinical comparison with H1N1-negative patients. J Infect Public Health. 2011 Nov;4(5-6):228-34. PMID:22118717

85. Ahmad AS, Puttaswamy C, Mudasser S, Abdelaziz O. Clinical Presentation and outcome in hospitalized patients of 2009 pandemic influenza A (H1N1) viral infection in Oman. Oman Med J. 2011 Sep;26(5):329-36. PMID:22125727

86. Arabi YM, Arifi AA, Balkhy HH, Najm H, Aldawood AS, Ghabashi A, et al. Clinical course and outcomes of critically ill patients with Middle East respiratory syndrome coronavirus infection. Ann Intern Med. 2014 Mar 18;160(6):389-97. PMID:24474051 